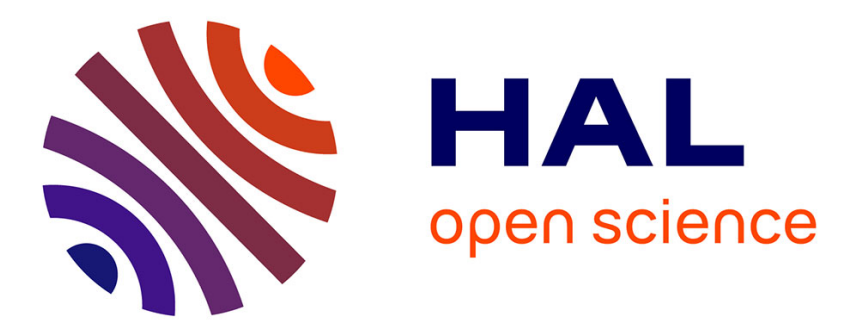

\title{
Lessons from nearly a century of the brand management system
}

\author{
Isabelle Aimé, Fabienne Berger-Remy, Marie-Eve Laporte
}

\section{To cite this version:}

Isabelle Aimé, Fabienne Berger-Remy, Marie-Eve Laporte. Lessons from nearly a century of the brand management system. Journal of Historical Research in Marketing, 2018, 10 (4), pp.420-450. 10.1108/JHRM-06-2017-0026 . hal-02045694

\section{HAL Id: hal-02045694 https://hal.science/hal-02045694}

Submitted on 22 Feb 2019

HAL is a multi-disciplinary open access archive for the deposit and dissemination of scientific research documents, whether they are published or not. The documents may come from teaching and research institutions in France or abroad, or from public or private research centers.
L'archive ouverte pluridisciplinaire HAL, est destinée au dépôt et à la diffusion de documents scientifiques de niveau recherche, publiés ou non, émanant des établissements d'enseignement et de recherche français ou étrangers, des laboratoires publics ou privés. 


\title{
Lessons from nearly a century of the Brand Management System
}

\begin{abstract}
Purpose - The aim of this essay is to perform a historical analysis of the Brand Management System(BMS) in order to understand why and how, over thepast century, theBMShas become the dominant marketing organizational model across Western countries and sectors and what the lessons are that can be learned from history to enlighten its current changes in today's digitized environment.

Me thodology/approach - Building on Low and Fullert on's work (1994), thepaper traces the evolution of the BMS from its creation in the 1930s to the recent digital era. Data from various sources - research papers, historical business books, case studies, newspaper articles, and internal documents - is analyzed to inform an intellectual historical analysis of the BMS's development.

Findings - The paper uses the prism of institutional isomorphism to highlight four distinct periods that show that the BMS has gradually imposed itself on the Westem world and managed to adapt to an ever-changing environment. Moreover, it shows that, in the current digital age, the BMS is now torn between two opposing directions: The brand manager should act as both absolute expert and galvanic facilitator and the BMS needs to reinvent itself once again.

O riginality/value - This paper provides a broad perspective on the BMS function to help marketing scholars, historians, and practitioners gain a better understanding of the issues currently facing the BMS and its relevance in the digital age.

Keywords - Brand, Brand Management System, Marketing organization, Marketing history, History of marketing thought

Paper type - General review
\end{abstract}

\section{Introduction}

The concept of the modern brand as we know it today in the Western world originated in the 19th century (Petty, 2012), when manufacturers started putting their names on their products to differentiate them from those of their competitors. At the time, brands were often named after their founders, e.g., King Camp Gillette in the US, Joseph Rowntree in the UK, Victor Auguste Poulain in France, and Werner von Siemens in Germany. Back then, brand management was not a formalized task, in part because it was their patronym, and company owners were taking care of it in an intuitive manner (Low and Fullerton, 1994). They decided nearly every move, as is evident in the operations of Henry Ford and his Model T (Tedlow, 1990), for example. Contextually, it should be noted that, "before 1914, there was no concept of the term 'marketing' in which product development, sales organization and advertising are integrated with the specific aim of satisfying consumer requirements" (Fitzgerald, 1995, p. 29). In fact, we can go as far as to say that brand management at that time was not even a serious concern (Tedlow, 1990, p15).

At the turn of the 20th century, brand management gradually shifted toward more specialization and marketing skills (Fitzgerald, 1995). This was the outcome of various inter-related, mutually reinforcing changes: (1) the launch of brand portfolios with fantasy brand names, which detached founders from the brands, (2) the arrival of the first generation of skilled marketing executives from business school, and (3) the development of advertising. As a result, brand management tasks were no longer held by top management but were functionally split between different departments (Low and Fullerton, 1994, p. 177). These functions could be internal or external to the company: In particular, working with advertising agencies became commonplace for “copywriting, art, and market research" (Keep et al., 1998, p. 34). Such agencies sometimes wielded tremendous brand decision power (Fitzgerald, 1995) and became the real masterminds of brand strategy (Marchand, 1991).

But in the late 1920s, an alternative organizational form arose "in which one individual [was] given the responsibility of planning, organizing, directing and controlling the marketing program for each of a company's several product lines or brands” (Fulmer and Brunner, 1968, p. 25). This new arrangement, known as the Brand Management System (BMS), "consisted basically in the creation of the brand group hierarchy composed of an assistant brand man, who was to perform much of the detail involved in the management of a particular brand and to serve as an understudy to his superior; the brand man; and the brand-group supervisors, each responsible for reviewing the work of two to four brand managers, who reported to the head of the brand-promotion division” (Fulmer, 1965, p. 65). Over time, the BMS organization, commonly credited to McElroy at Procter \& Gamble, became the norm in the Western world, with brand managers acting as "central coordinators of all marketing activities for their brand and responsible for developing and implementing the marketing plan" (Low and Fullerton, 1994, p. 173). Although repeatedly criticized, the BMS has proved itself adaptable to different types of companies and environments ever since, even though the two other competing forms of brand management (management by the founder or functional management) still exist, for instance in some start-ups. Today, criticism of the BMS is fiercer than ever before, as the digital era seems to require a rethinking of marketing organizations (Joshi and Giménez, 2014), as well as new skills from brand managers (De Swaan Arons et al., 2014). New specialist positions, such as digital privacy analysts or native-content editors, emerge and challenge the generalist position of brand managers (Brinker and McLellan, 2014). Many articles predict or recommend a real change in the BMS (Cooperstein, 2012; English, 2015). Some major fast-moving consumer 
good (FMCG) marketing departments like those of Danone or PepsiCo are undergoing massive changes with respect to their BMS (De Swaan Arons et al., 2014, p. 55).

Although a substantial body of literature addresses the BMS, it lacks a comprehensive picture of the evolution of this organizational form up to and including its recent development in today's digitized environment. This paper builds on the influential work of Low and Fullerton (1994) to create a historical analysis of the BMS and address two main concerns: (1) Why and how, over the course of a century, has the BMS changed from being an American FMCG prototype to being the dominant marketing organizational model across Western countries and sectors? And (2) what are the lessons that can be learned from history to illuminate the changes in the BMS today? To those ends, the research examines the origins of the BMS and its diffusion, investigates the forces behind the different stages it has undergone, and discusses its current status for both managers and scholars.

From a methodological standpoint, the BMS is analyzed from an intellectual history perspective, as defined by Fullerton and Punj (2004, p. 9): "Critical historical reasoning and evidence [is applied] to intellectual phenomena over time" to identify "what gives an idea intrinsic strength." It captures the richness and complexity of phenomena by investigating "the time, place and context," along with the intensity and reasons for the changes (Low and Fullerton, 1994, p. 174). Indeed, there are some complex events that history alone can tackle (Smith and Lux, 1993). It allows one to learn from the past (Shaw, 2015) and, in turn, "to inform current marketing research and practice" (Shaw, 2012, p. 30), since "the past causes the present, and so the future. Any time we try to know why something occurred [...] we have to look for factors that took shape earlier" (Stearns, 1998). Thus, it makes it possible to put so-called "marketing revolutions" into perspective (Volle, 2011) and understand the underlying structural movements behind current marketing practices (Shaw and Jones, 2005). Aligned with Suddaby (2016, p. 58), the historical approach is understood here as "one process of constructing knowledge, a social form of knowledge." The paper adopts the "context-driven periodization" approach recommended by Witkowski and Jones (2006, p. 77), as it proposes a temporal sequence of events and uses the major external events of the environment as turning points.

This work draws on marketing articles describing how to use the historical method (Golder, 2000; Nevett, 1991; Savitt, 1980; Smith and Lux, 1993). More specifically, the analysis follows Golder's five stages (2000, p. 158): "1. Select a topic and collect evidence," "2. Critically evaluate the sources of the evidence" (i.e., perform an "external criticism"), "3. Critically evaluate the evidence" (i.e., conduct an "internal criticism"), "4. Analyze and interpret the evidence," and "5. Present the evidence and conclusions." Starting with stage 1, it analyzes a wide and varied range of sources (see selected sources by era in Appendix 2). Paper selection was based on the following key words: brand manager, product manager, brand management system, product management system. Indeed, a difficulty and a limit of the data collection lie on the labeling of the functions, as many authors refer indifferently to "product managers" and "brand managers". As Fulmer (1965, p.70) noted, the understanding of marketing organizations "has been substantially clouded by an overlapping of several related terms". The selection includes 62 academic articles published in top-ranking journals between 1960 (Keith, 1960) and 2016 (Wedel and Kannan, 2016), historical business books (such as Dyer et al., 2004; Fitzgerald, 1995; Tedlow, 1990) and corporate archives (P\&G Heritage). In particular, the sources encompass 15 single case studies on specific organizations such as General Motors (Marchand, 1991; Townsend et al., 2010), Henkel (Brexendorf and Daecke, 2012), Kimberly Clark (Matanda and Ewing, 2012), Procter \& Gamble (Dyer et al., 2004; Gupta, 2003), Ford and Coca-Cola (Tedlow, 1990), and Rowntree (Fitzgerald, 1995). The latter is of particular interest, since it was a precursor to the broader adoption of marketing practices in the UK. The sources also take into account over 100 articles from professional and economic newspapers such as Forbes (Cooperstein, 2012), The Guardian (English, 2015), and the Financial Times (1886-2006) archives (Bingham, 2010), and 11 internal documents from cutting-edge consulting firms such as McKinsey (Bughin et al., 2015). Thanks to the wide pool of sources, this analysis is performed from three different perspectives: scholarly, professional, and expert, all playing important roles in the evolution of the BMS. The inclusion of top-level academic articles guarantees a high level of competence, objectivity, and reliability, and the multiplicity of sources facilitates corroboration of the evidence (Howell and Prevenier, 2001; Low and Fullerton, 1994). For example, several sources were used to assess where and when the Brand Management System really originated. To conduct the analysis and interpretation, each data set was analyzed separately.

The remainder of this article narrates how, through successive adaptations, the BMS has imposed itself over time as a dominant form of organization. It begins with the early years of the BMS in the 1920s-1940s, when it was thought of as brand-dedicated teams taking full responsibility. It goes on to describe how the BMS became the dominant marketing organization model in the consumer society of the 1950s-1970s before explaining how the pressure for accountability challenged the BMS in the 1980s and 1990s. Finally, it outlines the change that the BMS has undergone in today's digital era because of technological factors. These four eras, represented in Figure 1, are only meant to be used as a guide to illustrate the historical evolution of the BMS. The article concludes with a discussion of the results and the lessons for business and research. 
Figure 1: The four historical eras of the BMS

\section{The BMS gestational age (1920s-1940s)}

\section{The conception of the BMS}

Procter and Gamble (P\&G) is usually credited with creating the BMS (Dyer et al., 2004; Fulmer, 1965; Fulmer and Brunner, 1968; Gupta, 2003; Low and Fullerton, 1994; Schiller, 1988). However, the end of the 19th century had a few primitive predecessors. For example, "it is possible that the idea of having one individual with primary responsibility for a group of products originated in the department store; however, the department head of retail store is no more a product manager than is the production chief of a factory producing similar items or any manager with responsibility for some phase of the life cycle of one or more related products" (Fulmer, 1965, p. 65). Similarly, the title "product manager" was used at General Electric "as early as 1894," and some kind of "primitive" system existed at Libby, McNeil and Libby (Fulmer and Brunner, 1968, p. 25), but not the BMS as the marketing organization defined at the beginning of the present article. A need for more transversality across the different functions or divisions of multi-products firms - whether U-forms (unitary forms) or M-forms (multidivisional forms), as per Chandler's terminology (1962, 1977) - emerged in the 1910s and 1920s, but this was initially addressed with the creation of committees. For instance, a sales committee was created in 1911 at Rowntree, which then adopted a functional structure in 1921 following a trip by Seebhom Rowntree to the US and set up "a marketing committee in 1923 to predict and obtain the products needed in each successive year" (Fitzgerald, 1995, p. 208). Marketing and distribution were brought together as one single marketing department in 1931, again based on practices that another Rowntree director, George Harris, learned in the US. This marketing department had "overall charge for coordinating, developing and selling the products of every manufacturing unit (...) based upon similar practice current in the US since the Great War, [with] few parallels in Britain at that time" (Fitzgerald, 1995, p. 279), but it was not a BMS at this stage, and Rowntree did not adopt a divisional structure until 1962. At General Motors, a famous example of one of the first M-firms (Chandler, 1962, 1977), an institutional advertising committee was created in 1922 to get the divisions to work together to create an internal and external corporate image for the then "soulless corporation" (Marchand, 1991).

Subject to the same need for more transversality, Procter \& Gamble found an alternative solution, which was to become the norm. "Brand management emerged gradually and organically over the 1910s and 1920s as a new generation of managers rising to a senior status (...) decentralized responsibility for brand promotion," which was also the case with the launch of Crisco in 1911 (Dyer et al., 2004, p. 60). The BMS emerged as "a single, organic brand-building process" to face the crucial and rising need to seamlessly connect its "cutting-edge research and development" with the market research department (created in 1924) and coordinate marketing campaign, distribution, and production. "In January, 1928, Mr C. C. Uhling was made Procter and Gamble’s first brand manager when Lava soap was assigned to him” (Fulmer, 1965, p. 65). But the BMS's official formalization came on 13 May 1931 with the "McElroy memo" (Gupta, 2003) (see appendix). Neil McElroy was then a junior manager in P\&G's advertising department. While working on a campaign to support the Camay soap brand, he realized that the young brand was having a hard time competing "not only with soaps from Lever and Palmolive but also with Ivory, P\&G's flagship product” (McCraw, 2001). In response, and heeding his president's call for employee innovation to cope with the Great Depression, McElroy wrote the now famous three-page memo to advocate the creation of specific teams dedicated to each brand. Brands should be taken care of as if they are separate businesses, each with its own target group and positioning, in order to minimize internal cannibalization. According to this memo, a "brand man" should manage it and take "full responsibility" for all marketing aspects of it (Duffy, 2011), as if he were a "little general manager" (Buell, 1975, p. 6). As Dyer et al. (2004, p. 61) outline: "Specifically, McElroy's memo charged brand managers with studying shipments of their brands by units and territories, analyzing where sales were heavy and where they were light and extracting from that data, conclusions about which tactics were working. (...) In addition, the memo charged brand managers with studying the past advertising and promotional history of the brand as well as dealers and consumers within various territories (...) [and] work out sales helps and other necessary material.” The McElroy memo initiated the BMS that became quickly "a bedrock organizing principle” at P\&G (Dyer et al., 2004, p.61) and a strong asset for spectacular brand launch successes such as Tide in 1946. Neil McElroy went on to become P\&G’s president, and later the United States Secretary of Defense under President Dwight Eisenhower.

\section{A slow diffusion until after the Second World War}

Still, the BMS was largely ignored at the beginning, and its diffusion outside of P\&G was very slow at first. Most companies kept functional management for the next two decades, apart from four identified industrial US companies (Fulmer and Brunner, 1968; Low and Fullerton, 1994). Johnson and Johnson was the first to borrow it in 1935, followed by Monsanto in 1940 and Merck in 1946. The BMS "did not come into general use until the 
1950s” (Buell, 1975, p. 4). In addition, the name of this new organizational structure was not fixed and could vary. For instance, Buell (1975, p. 3) called it the "product management system.” Still, this organization could be considered the BMS, since the title of its main function (brand manager, product manager, or business manager) did "not alter the basic responsibilities" or the organization of the marketing department (Luck, 1969, p. 32).

How is it that the diffusion of the BMS took so long despite the renown and success of P\&G? The theory proposed by Rogers provides an initial answer (Low and Fullerton, 1994). It states that the diffusion of innovation needs time to spread from innovators to the majority through early adopters (Rogers, 1962). Also, the Second World War probably slowed the expansion of the BMS, as brands were no longer the main priority (Low and Fullerton, 1994). Moreover, in the US, many companies seemed to be satisfied with their functional management at the time. A few US companies had started to adopt a multidivisional organization, but they rather structured themselves “around geographic regions, as Sears \& Roebuck or Standard Oil” (Dyers et al., 2004), and General Motors, organized into product lines, had adopted the solution of interdivisional committees to ensure transversality, as mentioned above (Marchand, 1991). In European countries like the UK and France, "the continuance of family capitalism" could have "prevented salaried managers from becoming directors, and maintained conservative practices" (Fitzgerald, 1995, p. 191). The scale of the companies, not as big as in the US because of a smaller market size, also made the need for transversality across company departments less acute (Fitzgerald, 1995). Nonetheless, the BMS developed strongly in the 1950s-1970s in the Western world (Buell, 1975; Low and Fullerton, 1994), first in the US and then in Europe.

\section{The broad adoption of the BMS in the Western world (1950s-1970s)}

\section{The need to understand the consumer}

The years of reconstruction after the Second World War showed massive demographic and economic growth, which led to mass production, mass distribution, and mass consumption, as well as the development of a middle class seeking to "keep up with the Joneses". "The 1950s were an important decade in the development of marketing because for the first time mass consumption arrived for all but a small minority of the population” (Fitzgerald, 1995, p. 32). According to Tedlow's concept of "the third phase of American marketing” (1990, p. 6), those years have been characterized by "increasing market segmentation in terms of demographics (...) and psychographics to create divisions in markets that [marketers] can exploit with competitive advantages," which required marketing intelligence. In Europe, too, "mass manufacturing had made the intuition of the individual entrepreneurs less reliable and inappropriate” (Fitzgerald, 1995, p. 31).

As Fullerton (1988) and Volle (2011) have noted, a marketing analysis of consumer needs had already existed for a long time. Fullerton (1988, p. 114) stated, for instance, that "many large US firms had [their] own market analysis department by [the] 1920s." Here, again, P\&G proved to be a pioneer thanks to one of its executives, "Doc” Smelser. Around 1924 (Dyer et al., 2004) or 1925 (McCraw, 2001), he created what was then considered the most sophisticated internal marketing research department and headed it until 1959 (McCraw, 2001). And yet, initially, the "procedure was perfectly terrible by today's standards, Smelser later admitted" (Dyers et al. 2004, p. 58). Smelser put in place a team of door-to-door interviewers whose mission was to talk to consumers to extract data so that brand managers could fine-tune their marketing strategies. "The first brand to incorporate market research in its design was Camay" (Dyers et al., 2004, p. 58), and "this kind of market research became the hallmark of P\&G's approach to the development of new products and the continuous effort to improve existing ones" (McCraw, 2001). In the UK, a few companies imported market research in the 1920s1930s from the US, like Unilever or Rowntree, which used market research "to determine [their] policies in product development and marketing in the 1930s" (Fitzgerald, 1995, p. 32). But this remained the exception because "although inter-war marketing required the specialized services of agencies and became more professionalized within firms, few companies actually adopted market research or became 'marketing orientated'. (...) The methods of most forms in the United States and Britain did not change till the 1950s and 1960s" (Fitzgerald, 1995, p. 32).

However, after the Second World War more companies started to recognize the importance of their internal data to assess their markets better and organize their own market research departments. Moreover, the development of techniques such as consumer panel data usage (Wedel and Kannan, 2016) and focus groups (Merton, 1987) enabled larger-scale market data collection and analysis. Big market research companies were then available in North America and Europe to support marketers with, among others, the creation of Nielsen (1923), Burke (1931), and Gallup (1935) in the US, GfK (1934) in Germany, and IFOP (1938) in France (Volle, 2011; Wedel and Kannan, 2016). These market research firms developed their own tools to assess, for instance, sales data with household panels (following Nielsen's introduction of the first panel, the Nielsen Drug Index, in 1933), advertising efficiency with radio and television audience measurement systems (first introduced by Nielsen in 1936 for radio), and consumer attitudes and behaviors with field experiments. Such surveys could now even be conducted by telephone, to which an increasing number of households had access. Understanding the consumer became even more crucial, with the development of mass-media such as television and radio 
significantly increasing advertising expenses and, thus, the need for management and control (Fitzgerald, 1995; Tedlow, 1990).

\section{The BMS becomes the dominant marketing organization}

This increasingly systematic use of marketing data called for a new internal organization. Moreover, companies were becoming more and more complex, with higher numbers of product lines and brands and a need for more efficiency in their multidivisional structures (Low and Fullerton, 1994). "It is no coincidence that the marketing revolution was accepted between 1950 and 1970 both in the United States and in Britain as normative managerial practice. These were the same years in which managerial and company organization underwent change, and the multidivisional structure was adopted in the majority of large enterprises" (Fitzgerald, 1995, p. 32). As an illustration, it was stated in the first job advertisement for a product manager position, published on 4 July 1958 in the Financial Times: "He will need drive, enthusiasm and the ability to get things done, being required to take full responsibility for the successful promotion of the famous range of 3-in-one and Teals products”.

At this time, the BMS, which until then only P\&G and a few other big companies had established, became more visible and was regarded as a solution to these marketing and organizational needs. "The product manager system grew as an evolutionary necessity created by the increased complexity of marketing lines and marketing programs" (Fulmer and Brunner, 1968, p. 29). It subsequently expanded to the point of becoming "a fad" (Low and Fullerton, 1994, p. 182) in the 1950s-1960s among American companies or "the latest craze for the corporate board room set" (Fulmer and Brunner, 1968, p. 26), which led some firms to a hastened and poor implementation. "In the United States, acceptance of the product manager system is practically universal. At least two-thirds of consumer companies with multiple products now employ product managers in some capacity, (...) eighty-four per cent (...) among the largest 500 American corporations. (...) There are ample indications that some companies have adopted the practice with little justification other than their competitors have done it" (Fulmer and Brunner, 1968, p. 26). In 1974, the Association of National Advertisers estimated that 85\% of US packaged goods companies (actually, "93\% of those with annual advertising expenditures exceeding $\$ 10$ million”) and 55\% of those producing industrial goods had implemented the BMS (Buell, 1975, p. 4).

Having originated in the US, the BMS was subsequently transferred to subsidiaries abroad (Cunningham and Clarke, 1975; Venkatesh and Wilemon, 1980). Indeed, "as a management technology, product management was exported from the US to Europe, especially through the multinational corporations, to meet changing competitive environments" (Venkatesh and Wilemon, 1980, p. 68). In Germany, "the product manager seems to have made its first appearance (...) when a subsidiary of a consumer good company from Great Britain / Holland exported the concept from its North American operation. For over ten years, German product managers were exclusively employed in the subsidiaries of foreign based operations (primarily) from the United States. The first German company adopted the system in 1963” (Fulmer and Brunner, 1968, pp. 25-26). At the end of the 1960s, $75 \%$ of companies in Germany that had the BMS were American subsidiaries, and the BMS was still considered an American innovation, generating some sort of "nationalistic resentment" and skepticism about its interest in a country with smaller companies managing fewer product lines (Fulmer and Brunner, 1968). The situation developed similarly in other European countries, and in this way, the BMS ended up being used more broadly in the Western world. As an example, a job advertisement for Fisons Limited in the Financial Times, published on 4 February 1964, explicitly states that the recruited brand managers would be trained at the headquarters before being sent overseas.

Still, research hardly took an interest in the BMS during its first 30 years (Luck, 1969). “The concept developed entirely within the context of practical managerial necessity and only after two or three decades of its successful development did researchers begin to take note of it” (Venkatesh and Wilemon, 1980, p. 68). The first related article published in an academic journal was not even written by a scholar but by a marketing practitioner, Robert Keith (1960, p. 35), who described "the marketing revolution” that the BMS had brought to his own company, Pillsbury. Some researchers did not consider Keith's article a trustworthy academic resource and questioned the typicality of the Pillsbury case. For instance, Fullerton (1988, p. 105) writes that "somewhat cryptically, Keith termed Pillsbury's experience 'typical' (p. 36). He did not say of what it was typical and gave no evidence that other firms had undergone similar periods of development. Nonetheless, Pillsbury's experience often is presented as typifying that of most companies. Keith did not mention external economic and social conditions; most later writers have decided that the Great Depression of the 1930s brought the favorable conditions of the Production Era to an end and forced desperate businesspeople into the hard-sell orientation of the Sales Era." Still, this can be seen as a useful historical source of evidence as first-hand testimony by a witness of the early stages of BMS implementation. As a matter of fact, a significant number of scholarly articles on the topic would only come to be published in the 1970s and early 1980s. They studied, in particular, the responsibilities and interfaces of brand managers (Luck, 1969; Buell, 1975; Hise and Kelly, 1978; Cossé and Swan, 1983; McDaniel and Gray, 1980; Venkatesh and Wilemon, 1980; Lysonski, 1985). They noted that brand managers had major responsibilities, such as profit responsibility for their products or advertising, but little 
formal authority. As a result, it required influential power, which could be exerted thanks to legitimacy gained from recognized expertise, as well as personal attraction and charisma (Gemmill and Wilemon, 1972). Still, this was a shift from the initial concept of the "little general manager" (Buell, 1975, p. 6) to a charismatic influencer. This lack of formal authority (Gemmill and Wilemon, 1972; Venkatesh and Wilemon, 1976), combined with little experience (Giese and Weisenberger, 1982; Hise and Kelly, 1978; Venkatesh and Wilemon, 1980), frequently caused difficulties and weakened the BMS. As a consequence, since the early days of this era, the BMS was accused of producing brand bureaucracy, hindering creativity and customer-orientation (Hise and Kelly, 1978; Knox, 1994; Low and Fullerton, 1994; Shocker et al., 1994).

\section{The BMS under pressure to be accountable (1980s-1990s)}

\section{The globalization of brands}

At the turn of the 1980s, the world's equilibrium, which had been based on three main blocs (the Western allies, the Soviet bloc, and the Third World), started to wobble. After the end of the Cold War and the collapse of the Eastern Bloc, symbolized by the fall of the Berlin Wall on 9 November 1989, one form of a globalization process appeared to prevail: neoliberal globalization. Under the combined effect of greater openness in the markets, reduced transport costs, and increased human mobility, consumer goods were made available almost everywhere around the world. During this period, the number of organizations with global scope increased considerably. In a famous article titled “The globalization of markets” and published in the May-June 1983 issue of the Harvard Business Review, T. Levitt, a professor of economics at Harvard Business School, popularized the idea of a large market without frontiers that is achieved through a convergence of consumer needs and desires (Levitt, 1983): “companies must learn to operate as if the world were one large market - ignoring superficial regional and national differences” (Levitt, 1983, p. 92). In this context, building powerful brands capable of gaining consumer preference worldwide started to be seen as a core competency. Global brands were even playing a role as elements of the world culture: "Nothing confirms this as much as the success of McDonald's from the Champs Elysées to the Ginza, of Coca-Cola in Bahrain and Pepsi-Cola in Moscow, and of rock music, Greek salad, Hollywood movies, Revlon cosmetics, Sony televisions, and Levi’s jeans everywhere” (Levitt, 1983, p. 93).

Beyond the commercial possibilities offered by a global market, the idea was also to take advantage of economies of scale in manufacturing, promoting, advertising, and selling goods. To benefit from these economies of scale, most multinational companies engaged in rationalizing their brand portfolios by drastically downsizing the number of brands in order to retain a small group of large brands with global scope (Douglas et al., 2001; Hankinson and Cowking, 1997). Owing to the size and scope of these global brands, they were progressively viewed as financial assets, thanks to the brand valuation metrics appearing at the time. Rupert Murdoch included the values of his newspaper brands on the Australian News Group balance sheet in 1984; Interbrand valued the UK's Rank Hovis McDougall brands in 1988 and since then has published a ranking of the most valuable brands worldwide every year (Salinas and Ambler, 2009). From a name on a product, brands have become a source of competitive advantage for companies in the form of intangible assets, as they were seen as valuable, rare, inimitable, and non-substitutable resources (Barney, 1991).

This increasing recognition of financial brand equity put pressure on the brand management organization to be accountable as a strategic resource of the firm. The immediate effect was an organizational split between the strategic branding decisions on the one hand, made at a higher level in the company with the senior executive teams involved, and the execution tasks, which remained at the local level of the brand manager, on the other hand (Gates and Egelhoff, 1986). As described in a case study on Nestlé at the beginning of the 1980s (Hoff and Quelch, 1984), strategic decisions made centrally involved advertising campaign and package design as well as new product development; see also the article by Townsend and colleagues describing the organization at General Motors (Townsend et al., 2010). Dyers et al. (2004) described a similar organization in P\&G with, for instance, "Euro Brand Teams" to "leverage capabilities and scale across the region, coordinate new product and marketing initiatives and avoid costly duplication of effort” (p. 203). Meanwhile, issues like sales promotion were discussed at the country level.

\section{Greater accountability of brand managers}

Another derived effect was that brand managers were made more accountable for their results in brand building. Indeed, to realize their potential financial value, brands required a high level of investments such as advertising expenses. Therefore, this era was characterized by professionalization and standardization of the brand manager function (John and Martin, 1984) through formal processes and increased formal accountability. This transformation was achieved through the emergence and spread of computing in the professional context. Brand managers progressively used personal computers (desktops) and software, especially spreadsheets. The use of spreadsheets like Lotus (1983) and Excel (1985) greatly increased the pressure on control and monitoring 
systems, either internally (through dashboards and other balance scorecards) or externally (through computing market data).

Effects on the evolution of the brand manager's function were twofold: (1) Their tasks included a wider range of reporting, to the extent that the function sometimes turned into management accounting, and (2) they spent much more time crunching market data. Indeed, major market research companies launched retail panel data based on scanner data at that time, such as Nielsen point-of-sale scanner data in 1980 or IRI in-home barcode scanning service in 1995. This method implied better accuracy but also a higher frequency of issues and a larger amount of data collected.

\section{The rise of category management}

During the 1980s-1990s, fierce competition among retailers based on end-user prices to obtain market share led to greater concentration in the retail sector. As a consequence, the power of the retailers' purchasers increased during negotiation rounds. Manufacturers organized themselves differently to face retailer pressure and created the category management department (Hankinson and Cowking, 1997; Zenor, 1994). In 1987, P\&G was again a pioneer in the implementation of this new organization (Schiller, 1988), which is said to be "the most significant reorganization of the company in 30 years," according to Dyers et al. (2004, p. 198). It was also a response to the "internal competition among brand managers (...) as the company was missing opportunities to collaborate and share information and learning." The BMS was also criticized for not being able to lead a coordinated strategy in the product categories as "it was no one's business to identify segments and opportunities that might be served by line extensions or even new brands." The new Category Manager function "sought to redirect internal competition among brand managers outward, toward external competitors” (Dyers et al., p. 183) and initially competed with the BMS to the extent that some scholars predicted its gradual disappearance (see, among others, Lindblom and Olkkonen, 2006). As a matter of fact, as Dyers et al. underlined, "the general managers of the Category Business Units had reporting to them not only the brand managers in their portfolio but also representatives from sales, finance and product development. (...) P\&G was not adding a new layer of management but rather pushing some decision making down in the organization, closer to the operating level and the trade customers." Ultimately, the two organizational forms subsisted in parallel, creating a new interface for brand managers while somehow also diluting the power of brand managers, who were torn between the requirements of sales functions and those of management controllers (Chimhundu and Hamlin, 2007).

To sum up, in this era, brand managers tended to lose power in favor of sales, as they focused on planning and coordinating, mostly internally, without having a strategic orientation (Cossé and Swan, 1983). As they became more and more accountable, they acted as "good little soldiers" or nearly management accountants. Therefore, in losing sight of the market, they progressively departed from the original proposal and were even accused of damaging brand assets (Knox, 1994; Shocker et al., 1994; Starr and Bloom, 1994).

\section{A new BMS paradigm in the digital era (since 2000)}

\section{The development of marketing analytics}

Since the turn of the century, the digital era has brought a multiplicity of technological inventions that have transformed marketing practices. A few landmarks illustrate the changes in the economic environment and the unprecedented surge in available data. With the wide spread development of the World Wide Web starting in 1995, the development of clickstream data has boosted the launch of Customer Relationship Management (CRM) systems, such as Cloud Computing from Salesforce (1999). With the founding of Google in 1998, along with the advent of the keyword search, the volume and variety of data have increased dramatically with usergenerated content, for instance, taking the form of blogs or product reviews. The introduction of social media platforms - such as Facebook in 2004, YouTube in 2005, Twitter and Flickr in 2006, Tumblr in 2007, Instagram in 2010, and Snapchat in 2011 - has amplified the phenomenon by generating vast amounts of text and video data. Furthermore, the widespread use of smartphones equipped with a global positioning system (GPS) since the launch of the Apple iPhone in 2007 has enabled marketers to capture consumer location data.

As Wedel and Kannan (2016, p. 3) noted, all those innovations have "greatly reduced the variable cost of data collection and [have] resulted in unprecedented volumes of data that provide insights on consumer behavior at exceptional levels of depth and granularity.” According to Rust and Huang (2014, pp. 207-208), the impact of Information Technology (IT) on services is even greater, as it transforms the nature of service and leads to a "service revolution": "Service is not new; it is service plus IT that transforms service. IT enables service, and its input and output, information, is central to service."

As an indirect result, those technological advances influence brand management practices and prompt a reconsideration of the BMS (Joshi and Giménez, 2014). Numerous professional articles predict or recommend a real change in the BMS (among others, see Cooperstein, 2012, and English, 2015). 


\section{A shift toward more consumer-centric organizations}

Since the beginning of the $21^{\text {st }}$ century, much research and many case studies have noted that marketing organizations need to be more customer-oriented in order to better address the new digital and technological environment. In an in-depth study of 50 managers, Homburg et al. (2000, p. 467) found that "many firms that traditionally tended toward product-focused definitions of business units and which structured their sales units around geographies (typically, regions in the United States or countries in Europe) are redefining their business units from a customer perspective. While this does not mean completely abandoning the traditional orientations, their relative importance is diminishing.” In the new P\&G marketing organization implemented in 2000, Gupta (2003, p. 2) described the emergence of a "Cohort management strategy" targeting cohorts of consumers with similar attitudes and needs. Similarly, a Harvard Business School case (Shapiro, 2002) proposed as a best practice the creation of a customer-centric team by coordinating sales and marketing through a CRM program.

However, while some major marketing departments such as Nike or Pepsi Co. are undergoing massive changes in their BMS (De Swaan Arons et al., 2014; Lau et al., 2015), the organizational structure of the marketing departments in a large majority of companies - product or brand managers organized in silos - has not changed that much in the past 40 years. "Most marketing organizations are stuck in the last century," and CMOs are struggling to design efficient new organizations (De Swaan Arons et al., 2014, p. 55).

The move toward customer centricity seems to be so complex to implement that the McKinsey consulting firm recommends introducing a Chief Customer Officer (CCO) as a transitory stage to accelerate the process and break down the silos (Bughin et al., 2015). This new function is aimed at obtaining a master view of every customer through distinct sets of data and fostering co-creation by bringing customers directly into the creative process. Similarly, even though the BMS makes a significant contribution to company performance (Cui et al., 2014; Homburg et al., 2015), it is losing influence in favor of the sales department (Homburg et al., 2015), as was already observed in the previous era. Although this has not removed the brand manager function, it may reduce the influence and power of the BMS.

\section{A loss of control over brand management}

The digital age also changes the way marketers manage brands, leading to new paradigms in research. Quinton (2013) proposes a switch from the relational paradigm described by Louro \& Cunha (2001) to a community paradigm to better describe the current situation. As a matter of fact, the advent of social media has resulted in a fundamental shift in consumer interaction with brands that are present both off- and online, mainly with social conversation, co-creation, brand communities, mobile communication, and interactive gaming. By switching from conversation (top-down) to debate (multilayer interactions with multiple stakeholders), brand meaning is co-created during the consumer-brand relationship. The customer-perceived brand meaning is re-interpreted at each touchpoint that a consumer has with a managerially determined brand interface, a brand employee, or an external stakeholder. Iglesias \& Bonet (2012, p. 251) call this “persuasive brand management," as brand managers are progressively losing control over the multiple sources of brand meaning and are only co-producers of stories, rhetoric, and narratives to influence the meaning of the brand.

In this context, brand communication and management are no longer exclusively internally driven. There is a shift of power toward consumers through brand communities and co-creation, which are seen as ways to foster creativity. Consequently, brand managers are expected to acquire new social media skills (De Swaan Arons et al., 2014). Outside the company, brand managers now have to address fragmented specialist service providers. Inside the company, new specialist positions such as digital privacy analysts or native content editors emerge and challenge the generalist position of the brand manager (Brinker and McLellan, 2014). Moreover, as the sales department is in charge of the customer journey, it further challenges the brand managers' power (Homburg et al., 2015), even though the BMS is still recognized for making a significant contribution to company performance (Cui et al., 2014; Homburg et al., 2015).

\section{Brand managers as top-level facilitators}

Several researchers have emphasized the new key role of coordination assigned to the position of brand manager. While De Swann Arons et al. (2014, p. 60) use the word “orchestrator,” Brexendorf and Daecke (2012) underline that the tasks of brand managers have become more multi-faceted than ever before, as they need to integrate the new complex ecosystem inherited from digital advances, including the proliferation of touchpoints and customer journey management. The brand manager is now asked to "combine the insights of market and brand research with creative, entrepreneurial and implementation-oriented thinking” (Brexendorf and Daecke, 2012, p. 33), often in a global context. In this case, empowerment by top management is even more crucial, as global brands require high top-level coordination by creating tight relationships with the CEO, making certain that marketing goals support company goals, bridging organizational silos by integrating marketing and other disciplines, and ensuring that global, regional, and local marketing teams work interdependently. Taking the example of General Motors, Townsend, Cavusgil and Baba (2010) underscore the need to encompass both the 
commonalities and the divergences between markets (global orientation, global market knowledge competencies, and global coordination) and plead for global championship.

The brand manager's tasks are then expanded to include facilitation by acting as the spokesperson's office and communicating for societal purposes. However, these tasks are traditionally devoted to the communication team, often directly linked to the CEO, which is becoming a key interface for the BMS.

\section{New skills required}

Data-driven decision making poses obvious challenges concerning skills, as brand managers are now working at the intersections between marketing, statistics, econometrics, and IT (Joshi and Giménez, 2014). This means that they need to combine a double expertise. They are expected to have strategic and management skills while possessing a "broad and deep set of skills" (Wedel and Kannan, 2016, p. 20) to master different data and analytics requirements. Moreover, their knowledge has to be continuously updated in a fast-changing environment. "They must be strategists, allocating scarce resources to support company priorities and increasing return on investment. They must be technologists, tracking and capitalizing on the most useful of the sophisticated technologies that are flooding their field. In addition, they must be scientists, because the future of their business may not look much like the past” (Joshi and Giménez, 2014, p. 65). This leads to the emergence of more specialized marketing functions, such as that of Chief Marketing Technologist (CMT), who is a marketing analyst serving as a liaison between the Chief Marketing Officer (CMO) and other internal stakeholders like IT (Brinker and McLellan, 2014).

In terms of soft skills, experts say that the current brand manager should be able to work efficiently in crossfunctional teams and embrace a test-and-learn methodology with the development of experiments (De Baere, 2016; Joshi and Giménez, 2014). Collaboration and networking thus become new focuses of the BMS. Brand managers are now expected to "cross organizational boundaries" and "make and execute shared decisions" (Joshi and Giménez, 2014, pp. 65 and 67). These authors describe how companies like Target and Nordstrom have revamped their decision processes and improved collaboration between the BMS and other functions on planning and strategy, execution, and operations.

To conclude, in the current era, the brand managers are expected to be both galvanic facilitators able to federate people internally and externally around the brand mission and absolute experts mastering digital and analytical skills.

\section{Discussion and lessons learned from the BMS}

The BMS as an organization of the marketing departments originated 90 years ago in the US, became dominant in the Western world 40 years ago, and is still around despite recurring criticism and enormous changes in the environment. In organizational studies (DiMaggio and Powell, 1983; Lawrence and Suddaby, 2006), institutional approaches provide an insightful theoretical framework to understand how the BMS expanded successfully. DiMaggio and Powell (1983) developed the concept of institutional isomorphism to explain how organizations in the same field tend to become similar. This occurs through three different types of is omorphic processes that are not mutually exclusive and do not necessarily occur in this order: "mimetic," "normative," and/or "coercive isomorphic processes" (DiMaggio and Powell, 1983, p. 150). According to the authors, organizations in the same field tend to model themselves after renowned companies to appear more legitimate and cope with uncertainty; this is mimetic isomorphism. With employees changing firms and consulting firms advising new clients, the model gradually becomes a norm in the field; this is normative isomorphism. Eventually, companies may feel pressured to adopt the new model; this is coercive isomorphism. Looking at its history in the light of institutional isomorphism (see Figure 2 below), the BMS first became a marketing organization standard through mimetic isomorphism, when a few big companies copied the organization of P\&G in the 1930s-1940s. This development was followed by normative isomorphism, when most US companies implemented the BMS in the 1950s-1960s by applying the norm that these visible companies had established. Finally, it became coercive isomorphism when the US headquarters imposed organizational practices on their subsidiaries abroad (Kostova and Roth, 2002), including the BMS organization in the 1960s-1970s (Fulmer and Brunner, 1968; Townsend et al., 2010).

Figure 2: Diffusion of the BMS through institutional isomorphism

(quotations are from DiMaggio and Powell, 1983, pp. 150-151)

In terms of implementation, however, the BMS has moved far away from its original philosophy. Originally, it was supposed to encompass a team taking full responsibility for a brand (Duffy, 2011). But a critical-historical evaluation shows that the BMS was not adopted in this way and constantly adapted to a changing environment. This adaptive capacity explains why this organizational form survived and thrived. Four eras of the BMS have 
been identified. In the first period (1920s-1940s), brand managers were supposed to act as "little general managers" (Buell, 1975, p. 4). But in the second period (1950s-1970s), the implementation varied a lot from one company to another and caused some confusion, mainly due to a vague definition of the brand managers' roles and different levels of authority from one company to the next. For these reasons, the BMS could be seen simultaneously as “a panacea and a Pandora’s box” (Fulmer, 1965, p. 63). Still, when properly implemented, the new marketing organization helped prioritize customer needs over internal considerations and company executives' own preferences. Thus, it paralleled the adoption of a more marketing-driven, customer-centric orientation within companies. As a result, the brand manager acquired significant influence if little formal authority. Hence, the second period of the BMS can be considered its golden age. The brand managers subsequently lost managerial control to other departments - namely finance and sales - in the third period (1980s-1990s) and to consumers in the fourth period (since 2000). Data played a central role at the dawn of brand managers (first and second periods) and in their loss of influence (third and fourth periods). Indeed, the conception of the BMS and its subsequent broad adoption can be tied to a need for a more systematic use of data, so as to better know the market and consumer needs and to better address them. But in the next periods, brand managers seem to have been overwhelmed by the data. Increased accountability and more reporting tended to convert these marketers into data analysts during the third period (1980s-1990s). In the current period, it is not so much the use of data but their volume, velocity, and variety (together defining big data) that challenge brand managers. This big data coming from multiple touchpoints with consumers requires new technical skills once again. There is a risk that brand managers will lose sight of the big picture and stay data analysts - just like in the third era, but for a different type of data.

Today, the BMS is torn between two opposing but complementary directions: the galvanic facilitator and the absolute expert. The BMS's fourth period could give influential power back to brand managers by reconfiguring them into a hybrid form inherited from the two previous periods. Ideally, today's brand managers should be twoheaded. This poses significant challenges for the organization: The main one is to change from a hierarchical to a networked organization, a shift that seems unnatural for many FMCG companies. As the main result, it is questionable whether a single person can hold the position formerly held by a brand manager. This introduces the challenges of collaborative work in marketing, including organizational agility, cooperation rules, and network mastery. The most challenging task for managers, therefore, consists in breaking the silos while managing the overlaps. Joshi and Giménez (2014, p. 65) state that "to break down barriers, marketing pioneers are revamping the decision processes at the boundaries between functions, focusing on three areas: planning and strategy, execution, and operations and infrastructure.” Moreover, as the two required profiles (the galvanic facilitator and the absolute expert) stand miles apart in both behavior and mindset, the alchemy may produce a true management challenge. This situation questions both the decision-making process and the management control systems, which should be flexible enough to allow both cooperation and a trial-error approach. Lastly, one might rightfully wonder whether such a dichotomous picture is achievable in a single organization especially in large corporations, where the set of rules may prevent the galvanic facilitator from breaking the silos (Joshi and Giménez, 2014). Part of the solution may lie in large firms’ capacity to foster strategic brand venturing through spin-outs or alliances set apart from the existing business, obeying other rules (Van Rensburg, 2014). However, venturing teams inside marketing departments may stir organizational resistance, and the risk of failure is high. In fact, in the firms studied by Van Rensburg (2014, p. 13), "a 'failure' rate of 75 percent for brand intrapreneurial projects was acknowledged as a very creditable accomplishment.”

Finally, in the current era, the digital revolution leaves the BMS at crossroads. Companies are still unclear on the new positions required and their job description since so many specialized new skills are emerging in digital marketing. Should they hire specialists for each new kind of expertise? Should they work with external agencies that are experts in their own field? History could well repeat itself (Shaw and Jones, 2002). Other organizational forms, such as management by the founder/director or functional management, had existed before the BMS prevailed. Today's conditions show some resemblance with this pre-gestational age. Indeed, similarly to when advertising developed at the end of the 19th century, brand management could become functional again, with experts in specific areas - such as social media - devoting their time to several brands within the company, with or without the help of external agencies. Or, in a world where numerous start-ups are created by inspired founders, brand management could return to what it looked like in the 19th century, when owners created their own company and handled brand management themselves. This is similar to how Steve Jobs, renowned for distrusting market research, managed the Apple brand, or Elon Musk steers the Tesla brand. However, companies may face the very same difficulties as the ones that led to the BMS at the time. Once an improved way of managing brands emerges (and this may well be an adapted version of the BMS), one can expect more companies to adopt it through institutional isomorphism, copying their competitors (mimetic isomorphism), and hiring consultants who would disseminate the idea (normative isomorphism). Therefore, although many business analysts play the role of doomsayers and predict a revolution, history teaches us that the evolution of brand management could well be cyclical and that the BMS may reincarnate itself. 


\section{Conclusion}

In terms of academic implications, this article extends Low and Fullerton's historical analysis of the Brand Management System (1994) to today's digital world. It reveals why and how the BMS imposed itself as a major organizational form in Western countries throughout the 20th century and the first two decades of the 21st century while adapting to an ever-changing environment. The use of the neo-institutional framework (DiMaggio and Powell, 1983) has been crucial to show how the BMS became the dominant type of brand management in the US and then in Europe by outpacing alternative organizational forms such as functional brand management and top-level brand management. Low and Fullerton's approach was enriched by European case studies, such as Rowntree, which highlighted that the BMS started in the US and later spread to Western countries through the headquarters of American companies.

From a methodological standpoint, the present article confirms the interest of a historical approach to take a more objective perspective and avoid availability or recency bias, which occurs when current phenomena are overestimated because they are highly topical (Tversky and Kahneman, 1974). The historical methodology makes it possible to take a step back within a discipline and enhance it from a theoretical standpoint (Shaw, 2011, 2014). Thanks to this approach, the "marketing revolution" caused by digital transformation, as currently emphasized in the media, can be put into perspective and contemplated less emotionally: It is not the first time that the BMS is facing "revolutions," and it has always adapted before.

From a managerial standpoint, the research illustrates that companies should scrutinize the brand management function before redesigning their organizations. It is important to take a step back and not be influenced too much by all the fuss around digital transformation. Managers are tempted to create digital functions parallel to the current structure, thus recreating silos, whereas the whole brand management organization has to be re-engineered and "decompartmentalized" to increase networking and agility. As boundaries between brand management and other functions such as IT, sales, and finance blur with the rise of digital marketing, the interfaces between functions must be redefined. Finally, this research underlines the need to rethink brand management rules in the organization regarding decision making, role allocation, and control systems.

This research opens avenues for future research. It would be useful to pursue investigations in the first two periods of the BMS to see whether other types of brand management existed then outside of the US and Western Europe, for example in Japan. To this end, consultation of additional historical company books and corporate archives, as well as interviews with retired brand managers active at this time and in these geographical areas, would be of great value. Longitudinal case studies of single companies could also provide insightful testimonies. With regard to the last era, it would be interesting to examine the different organizational designs that companies are currently experimenting with to take into account the new skills required in digital marketing. For example, some companies focus on analyzing big data while others emphasize brand content. It would be useful to interview consultants in charge of digital marketing transformation to analyze the different forms that brand management is taking today in the different types of industries and geographical areas.

In conclusion, this historical perspective shows how adaptable the BMS has proved to be. The BMS originally developed from practical necessity: offering an integrated approach as opposed to fragmentation in a functional management, and specific expertise as opposed to intuitive management by founders or top executives. These practical necessities are more accurate than ever. Even though today, during these times of change, alternative forms of brand management have recaptured interest, the BMS could rise like a phoenix from the ashes of its previous lifecycle. The BMS may very well be the worst form of brand management, except for all the others.

\section{References}

Barney, J. (1991), “Firm resources and sustained competitive advantage”, Journal of Management, Vol. 17 No. 1, pp. 99-120.

Brexendorf, T.O. and Daecke, N. (2012), “The Brand Manager - Current Tasks and Skill Requirements in FMCG Companies”, Marketing Review St. Gallen, Vol. 29 No. 6, pp. 32-37.

Brinker, S. and McLellan, L. (2014), “The Rise of the Chief Marketing Technologist”, Harvard Business Review, Vol. 92 No. 7/8, pp. 82-85.

Buell, V.P. (1975), “The Changing Role of the Product Manager in Consumer Goods Companies”, Journal of Marketing, Vol. 39 No. 3, pp. 3-11.

Bughin, J., Chui, M. and Maniyka, J. (2015), “An executive’s guide to the Internet of Things”, McKinsey Digital - Raising Your Digital Quotient, pp. 124-131.

Chandler, A.D. (1977), The Visible Hand: The Managerial Revolution in American Business, Harvard University Press. 
Chandler, A.D. (1962), Strategy and Structure: Chapters in the History of the Industrial Enterprise, Doubleday \& Company, New-York.

Chimhundu, R. and Hamlin, R. (2007), “Future of the brand management structure in FMCG”, Journal of Brand Management, Vol. 14 No. 3, pp. 232-239.

Cooperstein, D. (2012), “Marketing Change Management - Like It Or Not, You Have To Figure It Out”, Forbes, 11 July, available at: http://www.forbes.com/sites/davidcooperstein/2012/07/11/marketing-changemanagement-like-it-or-not-you-have-to-figure-it-out/\#f46163513759 (accessed 16 December 2016).

Cossé, T.J. and Swan, J.E. (1983), “Strategic Marketing Planning by Product Managers-Room for Improvement?”, Journal of Marketing, Vol. 47 No. 3, p. 92.

Cui, A.P., Hu, M.Y. and Griffith, D.A. (2014), “What makes a brand manager effective?”, Journal of Business Research, Vol. 67 No. 2, pp. 144-150.

Cunningham, M.t. and Clarke, C. j. (1975), “The Product Management Function in Marketing”, European Journal of Marketing, Vol. 9 No. 2, p. 129.

De Baere, T. (2016), “The CMO’s Guide to Digital Marketing Organization Structures”, B2B Marketing Experiences, 17 April, available at: http://www.b2bmarketingexperiences.com/2016/04/cmos-guidedigital-marketing-organization-structures/.

De Swaan Arons, M., van den Driest, F. and Weed, K. (2014), “The Ultimate Marketing Machine”, Harvard Business Review, Vol. 92 No. 7/8, pp. 54-63.

DiMaggio, P.J. and Powell, W.W. (1983), “The iron-cage revisited: institutional isomorphism and collective rationality in organizational field”, American Sociological Review, Vol. 48 No. 2, pp. 147-160.

Dyer, D., Dalzell, F. and Olegario, R. (2004), Rising Tide: Lessons from 165 Years of Brand Building at Procter \& Gamble, Harvard Business Review Press, Boston.

Douglas, S.P., Craig, C.S. and Nijssen, E.J. (2001), “Executive Insights: Integrating Branding Strategy Across Markets: Building International Brand Architecture”, Journal of International Marketing, Vol. 9 No. 2, pp. 97-114.

Duffy, S. (2011), “The McElroy ‘Brand Man’ Memo turns 80”, available at: http://duffy.agency/the-mcelroybrand-man-memo-turns-80/.

English, P. (2015), “Big bang or little steps - business digital transformation in the US and UK”, The Guardian, 19 August, available at: https:/www.theguardian.com/media-network/2015/aug/19/us-uk-businessdigital-transformation-disney-burberry (accessed 16 December 2016).

Fitzgerald, R. (1995), Rowntree and the Marketing Revolution, 1862-1969, Cambridge University Press, Cambridge.

Fullerton, R.A. (1988), “How Modern is Modern Marketing? Marketing's Evolution and the Myth of the 'Production Era'”, Journal of Marketing, Vol. 52 No. 1, pp. 108-125.

Fullerton, R.A. and Punj, G.N. (2004), “Shoplifting as Moral Insanity: Historical Perspectives on Kleptomania”, Journal of Macromarketing, Vol. 24 No. 1, pp. 8-16.

Fulmer, R.M. (1965), “Product Management: Panacea or Pandora’s Box?”, California Management Review, Vol. 7 No. 4, pp. 63-74.

Fulmer, R.M. and Brunner, L. (1968), “An Analysis of US and German Practice of Product Management”, Management International Review, Vol. 8 No. 2/3, pp. 25-36.

Gates, S.R. and Egelhoff, W.G. (1986), “Centralization in Headquarters-Subsidiary Relationships”, Journal of International Business Studies, Vol. 17 No. 2, pp. 71-92.

Gemmill, G.R. and Wilemon, D.L. (1972), “The Product Manager as an Influence Agent”, Journal of Marketing, Vol. 36 No. 1, pp. 26-30.

Giese, T.D. and Weisenberger, T.M. (1982), “Product Manager in Perspective”, Journal of Business Research, Vol. 10 No. 3, pp. 267-277.

Golder, P.N. (2000), "Historical Method in Marketing Research with New Evidence on Long-Term Market Share Stability”, Journal of Marketing Research, Vol. 37 No. 2, pp. 156-172.

Gupta, V. (2003), “P\&G’s Brand Management System”, IBS Center for Management Research,Hyderabad, India..

Hankinson, G. and Cowking, P. (1997), "Branding in Practice: The Profile and Role of Brand Managers in the UK”, Journal of Marketing Management, Vol. 13 No. 4, pp. 239-264.

Hise, R.T. and Kelly, J.P. (1978), “Product Management on Trial”, Journal of Marketing, Vol. 42 No. 4, pp. 28 33.

Hoff, E.J. and Quelch, J.A. (1984), “Nestle S.A.: International Marketing”, Harvard Business Publishing, available at: http://www.iesep.com/en/nestle-s-a-international-marketing-a-23495.html (accessed 16 December 2016).

Homburg, C., Vomberg, A., Enke, M. and Grimm, P. (2015), “The loss of the marketing department’s influence: is it really happening? And why worry?”, Journal of the Academy of Marketing Science, Vol. 43 No. 1, pp. 1-13. 
Homburg, C., Workman Jr., J.P. and Jensen, O. (2000), "Fundamental Changes in Marketing Organization: The Movement Toward a Customer-Focused Organizational Structure”, Journal of the Academy of Marketing Science, Vol. 28 No. 4, p. 459.

Howell, M.C. and Prevenier, W. (2001), From Reliable Sources: An Introduction to Historical Methods, Cornell University Press, Ithaca, N.Y.

Iglesias, O. and Bonet, E. (2012), "Persuasive brand management - How managers can influence brand meaning when they are losing control over it”, Journal of Organizational Change Management, Vol. 25 No. 2, pp. 251-264.

John, G. and Martin, J. (1984), “Effects of Organizational Structure of Marketing Planning on Credibility and Utilization of Plan Output”, Journal of Marketing Research (JMR), Vol. 21 No. 2, pp. 170-183.

Jones, D.G.B. and Shaw, E.H. (2002), “A history of marketing thought”, Handbook ofMarketing, SAGE Publications, London.

Joshi, A. and Giménez, E. (2014), “Decision-Driven Marketing”, Harvard Business Review, Vol. 92 No. 7/8, pp. 64-71.

Keith, R.J. (1960), “The Marketing Revolution”, Journal of Marketing, Vol. 24 No. 3, pp. 35-38.

Keep, W.W., Hollander, S.C. and Dickinson, R. (1998), "Forces Impinging on Long-Term Business-to-Business Relationships in the United States: An Historical Perspective”, Journal of Marketing, Vol. 62 No. 2, pp. 31-45.

Knox, S. (1994), “Transforming Brand Management from a Functional Activity into a Core Process”, Journal of Marketing Management, Vol. 10 No. 7, pp. 621-632.

Kostova, T. and Roth, K. (2002), “Adoption of an Organizational Practice by Subsidiaries of Multinational Corporations: Institutional and Relational Effects”, Academy of Management Journal, Vol. 45 No. 1, pp. 215-233.

Lau, A., Singer, M. and Willmott, P. (2015), “When you're finished changing, you're finished”, McKinsey Digital - Raising Your Digital Quotient, December.

Lawrence, T.B. and Suddaby, R. (2006), “Institutions and Institutional Work”, in Clegg, S.R., Hardy, C., Lawrence, T.B. and Nord, W.R. (Eds.), The SAGE Handbook ofOrganization Studies, 2 edition (2013)., SAGE Publications Ltd, London, pp. 215-254.

Levitt, T. (1983), “The globalization of markets”, Harvard Business Review, Vol. 61 No. 3, pp. 92-102.

Lindblom, A. and Olkkonen, R. (2006), “Category management tactics: An analysis of manufacturers' control”, International Journal of Retail \& Distribution Management, Vol. 34 No. 6, pp. 482-496.

Louro, M. and Cunha, P. (2001), “Brand Management Paradigms”, Journal of Marketing Management, Vol. 17 No. 7-8, pp. 849-875.

Low, G.S. and Fullerton, R.A. (1994), "Brands, Brand Management, and the Brand Manager System: A CriticalHistorical Evaluation”, Journal of Marketing Research, Vol. 31 No. 2, pp. 173-190.

Luck, D.J. (1969), “Interfaces of a Product Manager”, Journal of Marketing, Vol. 33 No. 4, pp. 32-36.

Lysonski, S. (1985), “A Boundary Theory Investigation of the Product Manager’s Role”, Journal of Marketing, Vol. 49 No. 1, pp. 26-40.

Marchand, R. (1991), “The Corporation Nobody Knew: Bruce Barton, Alfred Sloan, and the Founding of the General Motors....”, Business History Review, Vol. 65 No. 4, p. 825.

Matanda, T. and Ewing, M.T. (2012), “The process of global brand strategy development and regional implementation”, International Journal of Research in Marketing, Vol. 29 No. 1, pp. 5-12.

McCraw, T.K. (2001), American Business Since 1920: How It Worked, 2 edition (2008)., Wiley-Blackwell, Wheeling, Ill.

McDaniel, C. and Gray, D.A. (1980), “The Product Manager”, California Management Review, Vol. 23 No. 1, pp. 87-94.

Merton, R.K. (1987), “The focused interview and focus groups:Continuities and discontinuities”, The Public Opinion Quarterly, Vol. 51 No. 4, pp. 550-566.

Nevett, T. (1991), “Historical Investigation and the Practice of Marketing”, Journal of Marketing, Vol. 55 No. 3 , pp. 13-23.

Procter and Gamble Heritage website available at: https://us.pg.com/who-we-are/heritage/history-of-innovation

Quinton, S. (2013), “The community brand paradigm: A response to brand management's dilemma in the digital era”, Journal of Marketing Management, Vol. 29 No. 7/8, pp. 912-932.

Rogers, E.M. (1962), Diffusion of Innovations, 5th Edition, 5th edition (2003)., Free Press, New York.

Rust, R.T. and Huang, M.-H. (2014), “The Service Revolution and the Transformation of Marketing Science”, Marketing Science, Vol. 33 No. 2, pp. 206-221.

Salinas, G. and Ambler, T. (2009), “A taxonomy of brand valuation practice: Methodologies and purposes”, Journal of Brand Management, Vol. 17 No. 1, pp. 39-61.

Savitt, R. (1980), “Historical Research in Marketing”, Journal of Marketing, Vol. 44 No. 4, pp. 52-58.

Schiller, Z. (1988), “The Marketing Revolution at Procter and Gamble”, BusinessWeek, 25 July, pp. 72-76. 
Shapiro, B.P. (2002), “Creating the Customer-Centric Team: Coordinating Sales and Marketing”, Harvard Business Review, available at: http://www.hbs.edu/faculty/Pages/item.aspx?num=16702 (accessed 16 December 2016).

Shaw, E.H. (2011), "A comment on the relationship between the history of marketing thought and the development of marketing theory”, Marketing Theory, Vol. 11 No. 4, pp. 491-494.

Shaw, E.H. (2012), "Marketing strategy:From the origin of the concept to the development of a conceptual framework", Journal of Historical Research in Marketing, Vol. 4 No. 1, pp. 30-55.

Shaw, E.H. (2014), “The quest for a general theory of the marketing system”, Journal of Historical Research in Marketing, Vol. 6 No. 4, pp. 523-537.

Shaw, E.H. (2015), "Educational lessons from the past - marketing textbooks during the Age of Enlightenment (16th to 18th Centuries)", Journal of Historical Research in Marketing, Vol. 7 No. 3, pp. 389-406.

Shaw, E.H. and Jones, D.G.B. (2005), “A history of schools of marketing thought”, Marketing Theory, Vol. 5 No. 3, pp. 239-281.

Shocker, A.D., Srivastava, R.K. and Ruekert, R.W. (1994), "Challenges and Opportunities Facing Brand Management: An Introduction to the Special Issue”, Journal of Marketing Research, Vol. 31 No. 2, pp. 149-158.

Smith, R.A. and Lux, D.S. (1993), “Historical Method in Consumer Research: Developing Causal Explanations of Change”, Journal of Consumer Research, Vol. 19 No. 4, pp. 595-610.

Starr, J., Richard G. and Bloom, P.N. (1994), “The Power Relationships of Brand Managers”, Marketing Letters, Vol. 5 No. 3, pp. 211-223.

Stearns, P.N. (1998), “Why Study History?”, American Historical Association, available at: https://www.historians.org/about-aha-and-membership/aha-history-and-archives/archives/why-studyhistory-(1998) (accessed 16 December 2016).

Tedlow, R.S. (1990), New and Improved: The Story of Mass Marketing in America, Basic Books, New-York.

Townsend, J.D., Cavusgil, S.T. and Baba, M.L. (2010), “Global Integration of Brands and New Product Development at General Motors”, Journal of Product Innovation Management, Vol. 27 No. 1, pp. 4965.

Tversky, A. and Kahneman, D. (1974), “Judgment under Uncertainty: Heuristics and Biases”, Science, Vol. 185 No. 4157, pp. 1124-1131.

Van Rensburg, D.J. (2014), "Brand intrapreneurs and brand managers: in search of disruption”, Journal of Business Strategy, Vol. 35 No. 4, pp. 29-36.

Venkatesh, A. and Wilemon, D. (1980), “American and European Product Managers: A Comparison”, Columbia Journal of World Business, Vol. 15 No. 3, pp. 67-74.

Venkatesh, A. and Wilemon, D.L. (1976), “Interpersonal Influence in Product Management”, Journal of Marketing, Vol. 40 No. 4, pp. 33-40.

Volle, P. (2011), “Marketing: comprendre l'origine historique”, in Lehu, J.-M. (Ed.), MBA Marketing, Editions Eyrolles, pp. 23-45.

Wedel, M. and Kannan, P.K. (2016), “Marketing Analytics for Data-Rich Environments”, Journal of Marketing, Vol. 80 No. 6, pp. 97-121.

Witkowski, T.H. and Jones, D.G.B. (2006), “Qualitative Historical Research in Marketing”, Handbook of Qualitative Research Methods in Marketing, Edward Elgar Publishing, Cheltenham, UK, pp. 70-82.

Zenor, M.J. (1994), “The profit benefits of category management”, Journal of Marketing Research, pp. $202-213$. 
FIGURES

FIGURE 1: THE FOUR HISTORICAL ERAS OF THE BMS

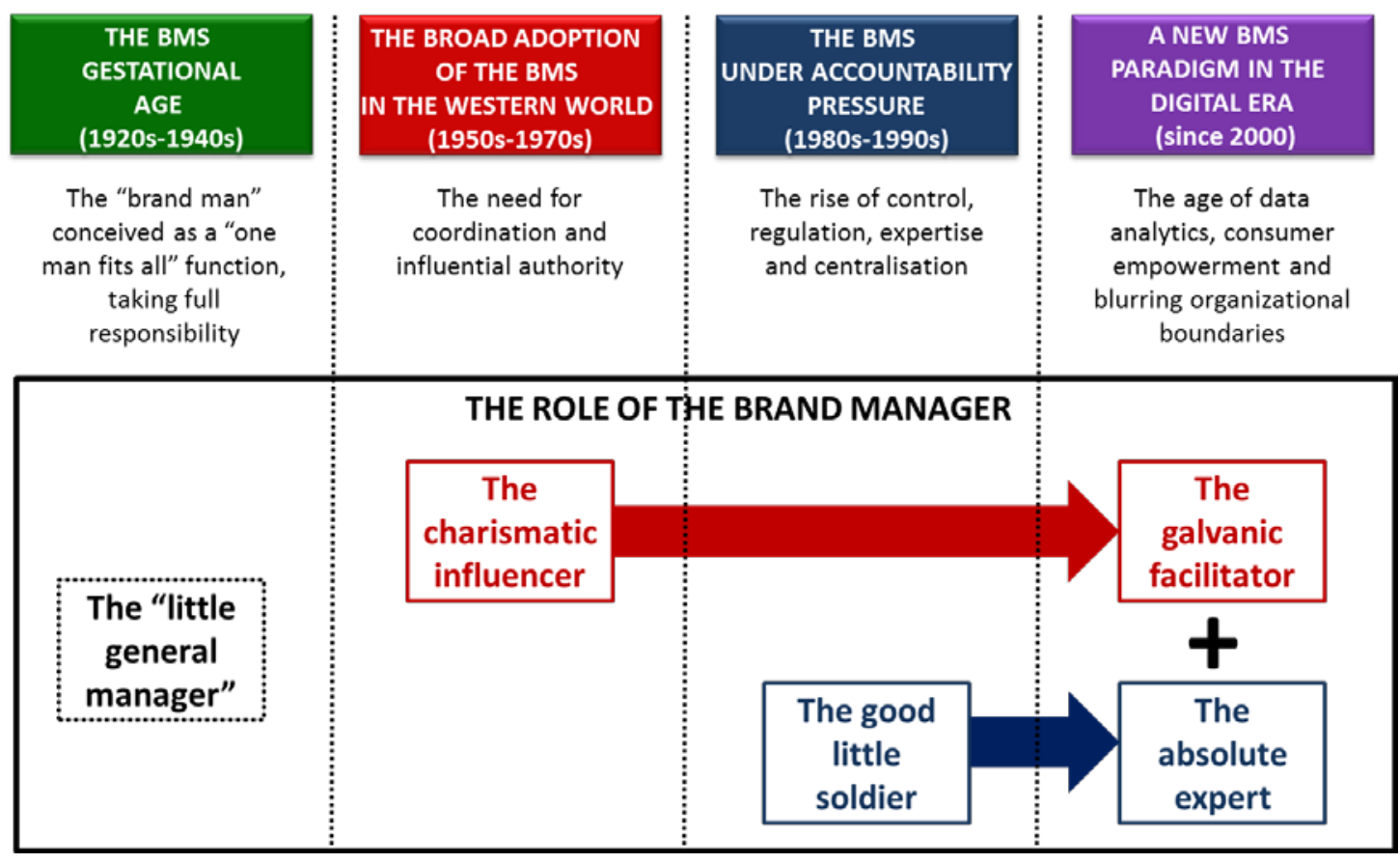


FIGURE 2: DIFFUSION OF THE BMS THROUGH INSTITUTIONAL ISOMORPHISM

(QUOTATIONS ARE FROM DIMAGGIO AND POWELL, 1983, PP. 150-151)

Mimetic isomorphism: "resulting from standard responses to uncertainty"

A few big, fast-moving consumer goods companies borrow

BMS, P\&G's innovation, in the 1930s-1940s.

Normative isomorphism: "associated with professionalization"

The BMS quickly develops as of the 1950s in the US, where it

stands out as the norm in the 1960s.

Coercive isomorphism: "stems from political

influence and the problem of legitimacy"

The BMS is transferred to the European subsidiaries starting

in the 1950s and becomes the dominant type of brand

management in the 1970 s. 


\section{APPENDIXES}

\section{APPENDIX 1: THE MCELROY MEMO}

C MARKETING
${ }_{\mathrm{P}}$ - Brand Teaus, 1931

cc: Mr. W. G. Werner

Mr. N. H. MeElroy

Mr. R. F. Rogan
May 13, 1931

ADV**N. H. MCELROY

Because I think it may be of some help to you in putting through our recommendation for additional men for the Promotion Department, I am outlining briefly below the duties and responsibilities of the brand men.

This outline does not represent the situation as it is but as we will have it when we have sufficient man power. In past years the brand men have been forced to do work that should have been passed on to assistant brand men, if they had been available and equal to the job.

\section{Brand Man}

(1) Study carefully shipments of his brands by units:

(2) Where brand development is heavy and where it is progressing, examine carefully the combination of effort that seems to be clicking and try to apply this same treatment to other territories that are comparable.

(3) Where brand develorment is light

(a) Study the past advertising and promotional history of the brand; study the territory personally at f1rst hand - both dealers and consumers - in order to find out the trouble.

(b) After uncovering our weakness, develop a plan that can be applied to this local sore spot. It is necessary, of course, not simply to work out the plan but also to be sure that the amount of money proposed can be expected to produce results at a ressonable cost per case.

(c) Outline this plan in detail to the Division Manager under whose jurisdiction the weak territory is, obtain his authority and support for the corrective action. 
Mr. R. F. Rogan

$$
-2-
$$

(d) Prepare sales helps and all other necessary material for carrying out the plan. Pass it on to the districts. Work with the salesmen while they are getting started. Follow through to the very finish to be sure that there is no let-down in sales operation of the plan.

(e) Keep whatever records are necessary, and make whatever fleld studies are necessary to determine whether the plan has produced the expected results.

(4) Take full responsibility, not simply for criticizing individual pieces of printed word copy, but also for the general printed word plans for his brands.

(5) Take full responsibility for all other advertising expenditures - Field, D.C.A. etc. - on his brands:

(6) Bxperiment with and recommend wrapper revisions.

(7) See each District Manager a number of times a year to discuss with him any possible faults in our promotion plans for that territory.

In short, when the brand men have approached their fullest responsibilities, they should be able to take from the shoulders of the Division Managers and of the District Managers a very heavy share of individual brand responsibility. This would leave the sales heads in a much freer position to administer the sales policies of the Company and apply general volume pressure without having to give such a large proportion of their time to thought on how to bring up volume on a certain brand in a certain part of the territory.

\section{Assistant Brand Man}

(1) Take care of the office work wh1ch w1ll have been laid out by the brand man, which must be followed through, checked and edited.

(2) Make field studies as directed by the brand man. 
Mr. R. F. Rogan

$$
-3-
$$

(3) Keep in touch with all printed word, field and D.C.A. plans.

(4) Finally, be able to step into the shoes of his superior at a moment's notice.

\begin{abstract}
With the above outline of responsibilities it is not hard to understand that one man should not have to work on more than two brands at the very most. I am sure that the need for a croup Products brand man, part of whose responsibility will be chain and voluntary chain promotion, will be equally obvious.
\end{abstract}

\title{
Group Products Check-Up Men
}

The brand men in the past have unfortunately been tied up too closely to their offlce work because their assistants have had to be out of the office on field check-ups a large share of the time: A great majority of these checking jobs could be handled by less responsible men than assistant brand men.

We believe that we can relieve the entire situation by adding to our organization two men - and perhaps more as their need is felt - whose dutles would be field checking on all products. These men would relleve the assistant brand men of a good share of their traveling. This, in turn, would allow the brand men to pass over to their assistants office work which is keeping them from their more important field studies.

With these two men our organization would be lined up as shown on the attached chart headed "Division of Brand Responsibilities in 6-Man Organization."

N. H. MoELROY 
APPENDIX 2: SELECTED SOURCES FOR THE CHARACTERIZATION OF EACH ERA

$1^{\text {st }}$ Era: the BMS gestational age (1920s-1940s)

\begin{tabular}{|c|c|c|c|c|c|c|c|}
\hline & \multirow[t]{2}{*}{ Theme } & \multirow[t]{2}{*}{ Source } & \multirow{2}{*}{$\begin{array}{l}\text { Nature } \\
\text { of the } \\
\text { source }\end{array}$} & \multicolumn{2}{|c|}{ Geography } & \multirow{2}{*}{$\begin{array}{l}\text { Business } \\
\text { sector }\end{array}$} & \multirow{2}{*}{$\begin{array}{c}\text { Main idea / } \\
\text { facts }\end{array}$} \\
\hline & & & & $\begin{array}{c}\text { Institutio } \\
n\end{array}$ & $\begin{array}{l}\text { Empiric } \\
\text { al data }\end{array}$ & & \\
\hline \multirow{2}{*}{$\begin{array}{l}\mathbb{\varangle} \\
\frac{1}{0} \\
\sum_{0}^{n}\end{array}$} & $\begin{array}{l}\text { A need for } \\
\text { more } \\
\text { professionalis } \\
\text { m in brand } \\
\text { management }\end{array}$ & $\begin{array}{l}\text { McElroy } \\
\text { memo } \\
(1931)\end{array}$ & $\begin{array}{c}\text { Internal } \\
\text { memo } \\
\text { at } P \& G\end{array}$ & USA & USA & FMCG & $\begin{array}{l}\text { Definition } \\
\text { of the } \\
\text { different } \\
\text { roles which } \\
\text { should be } \\
\text { handled by } \\
\text { a "brand } \\
\text { man" }\end{array}$ \\
\hline & $\begin{array}{l}\text { A need for } \\
\text { more } \\
\text { authority in } \\
\text { marketing }\end{array}$ & $\begin{array}{l}\text { McElroy } \\
\text { memo } \\
(1931)\end{array}$ & $\begin{array}{c}\text { Internal } \\
\text { memo } \\
\text { at } P \& G\end{array}$ & USA & USA & FMCG & $\begin{array}{l}\text { The "brand } \\
\text { man" } \\
\text { should have } \\
\text { full } \\
\text { responsibilit } \\
\text { y of the } \\
\text { brands they } \\
\text { take care of }\end{array}$ \\
\hline \multirow{2}{*}{ 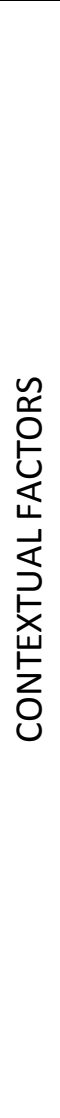 } & Technology & $\begin{array}{l}\text { Fitzgeral } \\
\text { d (1995), } \\
\text { Dyer et } \\
\text { al (2004), } \\
\text { Marchan } \\
\text { d (1991) }\end{array}$ & $\begin{array}{l}\text { Historic } \\
\text { al books } \\
\text { and } \\
\text { research } \\
\text { article } \\
\text { using a } \\
\text { historica } \\
\text { I } \\
\text { approac } \\
\text { h }\end{array}$ & USA, UK & $\begin{array}{l}\text { USA, } \\
\text { UK }\end{array}$ & $\begin{array}{c}\text { FMCG } \\
\text { (Rowntre } \\
\text { e, P\&G), } \\
\text { car } \\
\text { industry } \\
\text { (GM) }\end{array}$ & $\begin{array}{l}\text { Rise of } \\
\text { advertising } \\
\text { and market } \\
\text { research } \\
\text { requiring } \\
\text { new skills }\end{array}$ \\
\hline & $\begin{array}{l}\text { Social } \\
\text { transformatio } \\
\text { ns }\end{array}$ & $\begin{array}{l}\text { Fitzgeral } \\
\text { d (1995), } \\
\text { Dyer et } \\
\text { al (2004) }\end{array}$ & $\begin{array}{l}\text { Historic } \\
\text { al books }\end{array}$ & UK, USA & $\begin{array}{l}\text { UK, } \\
\text { USA }\end{array}$ & $\begin{array}{c}\text { FMCG } \\
\text { (Rowntre } \\
\text { e, P\&G) }\end{array}$ & $\begin{array}{l}\text { Limits of } \\
\text { family } \\
\text { capitalism: } \\
\text { manageme } \\
\text { nt no longer } \\
\text { left } \\
\text { exclusively } \\
\text { to family } \\
\text { directors, } \\
\text { recruitment } \\
\text { of external } \\
\text { managers } \\
\text { educated in } \\
\text { universities }\end{array}$ \\
\hline
\end{tabular}


The $2^{\text {nd }}$ Era: the broad adoption of the BMS in the western world 1950-1970

\begin{tabular}{|c|c|c|c|c|c|c|c|}
\hline & \multirow[t]{2}{*}{ Theme } & \multirow[t]{2}{*}{ Source } & \multirow[t]{2}{*}{ Nature of the source } & \multicolumn{2}{|c|}{ Geography } & \multirow[t]{2}{*}{ Business sector } & \multirow[t]{2}{*}{ Main idea / facts } \\
\hline & & & & Institution & $\begin{array}{l}\text { Empirical } \\
\text { data }\end{array}$ & & \\
\hline \multirow{6}{*}{$\begin{array}{l}\mathbb{\nwarrow} \\
\stackrel{1}{0} \\
\sum_{0}^{n}\end{array}$} & \multirow{3}{*}{$\begin{array}{l}\text { The influential } \\
\text { power of the } \\
\text { brand manager } \\
\text { as a native } \\
\text { characteristic }\end{array}$} & Keith (1960) & Case study Pillsbury & USA & USA & FMCG & $\begin{array}{l}\text { Marketing becomes the key } \\
\text { function in a consumercentric } \\
\text { approach. Brand managers are } \\
\text { its backbone }\end{array}$ \\
\hline & & $\begin{array}{l}\text { Gemmill \& Wilemon } \\
(1972)\end{array}$ & $\begin{array}{c}\text { Empirical research } \\
\text { paper }\end{array}$ & USA & USA & $\begin{array}{c}7 \text { large } \\
\text { companies }\end{array}$ & Referent power of the BM \\
\hline & & $\begin{array}{l}\text { Mc Daniel \& Gray } \\
(1980)\end{array}$ & $\begin{array}{c}\text { Empirical research } \\
\text { paper }\end{array}$ & USA & USA & FMCG & $\begin{array}{l}\text { Profile of the typical PMshows } \\
\text { that this is not a junior function }\end{array}$ \\
\hline & \multirow{3}{*}{$\begin{array}{l}\text { Authority } \\
\text { and } \\
\text { legitimacy } \\
\text { coming from } \\
\text { charismatic } \\
\text { skills }\end{array}$} & Luck (1969) & $\begin{array}{l}\text { Empirical research } \\
\text { paper }\end{array}$ & USA & USA & $\begin{array}{l}\text { Pharmaceutical } \\
\text { industry and } \\
\text { other } \\
\text { industries }\end{array}$ & $\begin{array}{l}\text { PM is a pivotal function with } \\
\text { numerous interfaces requiring } \\
\text { cooperation skills }\end{array}$ \\
\hline & & Buell (1975) & $\begin{array}{l}\text { Empirical research } \\
\text { paper; research } \\
\text { funded by the } \\
\text { Association of } \\
\text { National Advertisers }\end{array}$ & USA & USA & $\begin{array}{c}20 \text { large } \\
\text { companies }\end{array}$ & $\begin{array}{l}\text { PM characterized by group } \\
\text { cooperation and participative } \\
\text { decision making rather than } \\
\text { classical hierarchy }\end{array}$ \\
\hline & & $\begin{array}{l}\text { Venkatesh \& } \\
\text { Willemon (1976) }\end{array}$ & $\begin{array}{l}\text { Empirical research } \\
\text { paper }\end{array}$ & USA & USA & FMCG & $\begin{array}{l}\text { Interpersonal influence of PMas } \\
\text { a key characteristic }\end{array}$ \\
\hline
\end{tabular}


The $3^{\text {rd }}$ Era: the BMS under accountability pressure 1980s-1990s

\begin{tabular}{|c|c|c|c|c|c|c|c|}
\hline & \multirow{2}{*}{ Theme } & \multirow{2}{*}{ Source } & \multirow{2}{*}{ Nature of the source } & \multicolumn{2}{|c|}{ Geography } & \multirow{2}{*}{$\begin{array}{l}\text { Business } \\
\text { sector }\end{array}$} & \multirow{2}{*}{ Main idea / facts } \\
\hline & & & & Institution & $\begin{array}{l}\text { Empirical } \\
\text { data }\end{array}$ & & \\
\hline \multirow{9}{*}{ 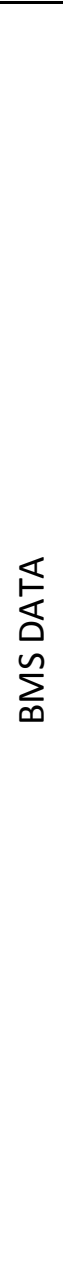 } & \multirow{6}{*}{$\begin{array}{l}\text { Decreasing } \\
\text { power of the } \\
\text { brand manager }\end{array}$} & $\begin{array}{l}\text { Mc Daniel and Gray } \\
(1980)\end{array}$ & $\begin{array}{c}\text { Empirical research } \\
\text { article }\end{array}$ & USA & USA & $\begin{array}{l}\text { Consumer } \\
\text { goods }\end{array}$ & $\begin{array}{l}\text { Concerns about authority/ } \\
\text { responsibility imbalance }\end{array}$ \\
\hline & & $\begin{array}{l}\text { Cossé and Swan } \\
\text { (1983) }\end{array}$ & $\begin{array}{l}\text { Empirical research } \\
\text { article }\end{array}$ & USA & USA & $\begin{array}{c}\text { Large } \\
\text { companies }\end{array}$ & $\begin{array}{l}\text { PM focused on short term } \\
\text { issues, no strategic orientation }\end{array}$ \\
\hline & & Knox (1994) & $\begin{array}{l}\text { Empirical research } \\
\text { article }\end{array}$ & UK & UK & $\begin{array}{c}\text { Large } \\
\text { companies }\end{array}$ & $\begin{array}{l}\text { Inadequacy of BM, not } \\
\text { responsive enough (should be } \\
\text { closer to the market and reactive } \\
\text { vs innovation) }\end{array}$ \\
\hline & & $\begin{array}{l}\text { Shocker et al. } \\
\text { (1994) }\end{array}$ & Theoretical article & USA & & & $\begin{array}{l}\text { Local BMs lose power against } \\
\text { teams at central level }\end{array}$ \\
\hline & & $\begin{array}{l}\text { Starr and Bloom } \\
\text { (1994) }\end{array}$ & $\begin{array}{c}\text { Empirical research } \\
\text { article }\end{array}$ & USA & USA & $\begin{array}{l}\text { Industrial } \\
\text { /packaged } \\
\text { goods }\end{array}$ & $\begin{array}{l}\text { BM less influential than other } \\
\text { department such as Sales or } \\
\text { Manufacturing }\end{array}$ \\
\hline & & Zenor (1994) & $\begin{array}{c}\text { Empirical research } \\
\text { article }\end{array}$ & USA & USA & $\begin{array}{l}\text { Consumer } \\
\text { goods }\end{array}$ & $\begin{array}{l}\text { Category managers compete } \\
\text { internally with BMs }\end{array}$ \\
\hline & \multirow{3}{*}{$\begin{array}{l}\text { Authority and } \\
\text { legitimacy } \\
\text { coming from } \\
\text { specific } \\
\text { competencies } \\
\text { and expertise }\end{array}$} & $\begin{array}{l}\text { Hise and Kelly } \\
\text { (1978) }\end{array}$ & $\begin{array}{c}\text { Empirical research } \\
\text { article } \\
\end{array}$ & USA & USA & $\begin{array}{c}97 \text { large } \\
\text { companies }\end{array}$ & $\begin{array}{l}\text { BMs are experts in advertising } \\
\text { and market research }\end{array}$ \\
\hline & & $\begin{array}{l}\text { Venkatesh and } \\
\text { Willemon (1980) }\end{array}$ & $\begin{array}{c}\text { Empirical research } \\
\text { article }\end{array}$ & USA & $\begin{array}{l}\text { USA and } \\
\text { Europe }\end{array}$ & $\begin{array}{l}\text { Industrial } \\
\text { /packaged } \\
\text { goods }\end{array}$ & $\begin{array}{l}\text { BMS are based on similar } \\
\text { competencies in Europe and the } \\
\text { USA; the BMS originated in the } \\
\text { USA and has been transferred to } \\
\text { European subsidiaries. }\end{array}$ \\
\hline & & Rangan and Michael & Case study & USA & World & GE Plastics & A functional structure is \\
\hline
\end{tabular}




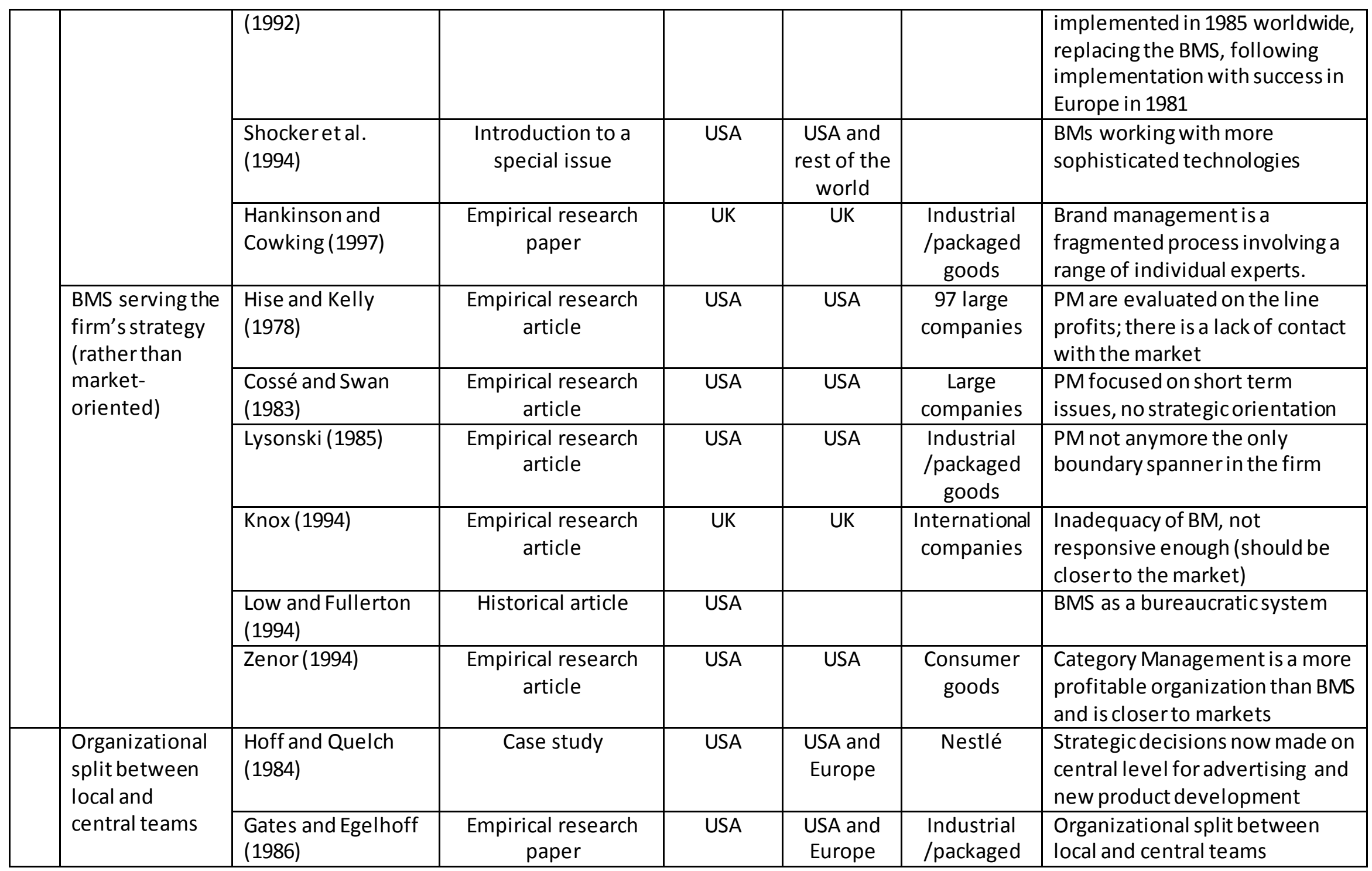




\begin{tabular}{|c|c|c|c|c|c|c|c|}
\hline & & & & & & goods & \\
\hline & & Quelch (1993) & Case study & USA & $\begin{array}{l}\text { USA and } \\
\text { Europe }\end{array}$ & Nestlé & $\begin{array}{l}\text { Organization in SBU (Strategic } \\
\text { Business Units) to replace } \\
\text { organization by products, with } \\
\text { enlarged responsibilities }\end{array}$ \\
\hline & & Dyer et al. (2004) & Historical book & USA & USA & $P \& G$ & $\begin{array}{l}\text { Creation of brand teams at } \\
\text { European level at P\&G }\end{array}$ \\
\hline \multirow{4}{*}{ 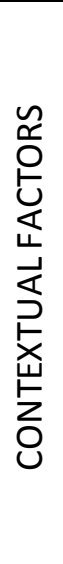 } & \multirow[t]{2}{*}{ Technology } & $\begin{array}{l}\text { Salinas and Ambler } \\
\text { (2009) }\end{array}$ & $\begin{array}{l}\text { Research paper using } \\
\text { some historical } \\
\text { approach }\end{array}$ & UK & $\begin{array}{l}\text { UK, some } \\
\text { European } \\
\text { countries }\end{array}$ & & $\begin{array}{l}\text { Brand financial valuation metrics } \\
\text { appears in the } 80 \mathrm{~s}\end{array}$ \\
\hline & & $\begin{array}{l}\text { Wedel and Kannan } \\
\text { (2016) }\end{array}$ & $\begin{array}{l}\text { Research paper using } \\
\text { a historical approach }\end{array}$ & USA & $\begin{array}{l}\text { USA and } \\
\text { Europe }\end{array}$ & $\begin{array}{l}\text { Companies } \\
\text { and agencies }\end{array}$ & $\begin{array}{l}\text { Market research companies } \\
\text { provide scanner data }\end{array}$ \\
\hline & \multirow[t]{2}{*}{$\begin{array}{l}\text { Social } \\
\text { transformations }\end{array}$} & Levitt (1983) & Theoretical article & USA & & & $\begin{array}{l}\text { Globalization of markets and } \\
\text { consumption culture }\end{array}$ \\
\hline & & Quelch and Harding & Theoretical article & USA & USA / UK & & $\begin{array}{l}\text { More power to retail; rise of } \\
\text { private lables }\end{array}$ \\
\hline
\end{tabular}

The 4th Era: A new BMS paradigm in the digital era (since 2000)

\begin{tabular}{|c|c|c|c|c|c|c|c|}
\hline & \multirow[t]{2}{*}{ Theme } & \multirow[t]{2}{*}{ Source } & \multirow[t]{2}{*}{ Nature of the source } & \multicolumn{2}{|c|}{ Geography } & \multirow{2}{*}{$\begin{array}{c}\text { Business } \\
\text { sector }\end{array}$} & \multirow[t]{2}{*}{ Main idea / facts } \\
\hline & & & & Institution & $\begin{array}{c}\text { Empirical } \\
\text { data }\end{array}$ & & \\
\hline \multirow{2}{*}{ 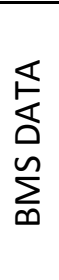 } & \multirow[t]{2}{*}{$\begin{array}{l}\text { A shift toward } \\
\text { more consumer- } \\
\text { centric } \\
\text { organizations }\end{array}$} & Homburg et al. (2000) & $\begin{array}{l}\text { Empirical research } \\
\text { paper }\end{array}$ & Germany & $\begin{array}{l}\text { Germany + } \\
\text { USA }\end{array}$ & Industry & $\begin{array}{l}\text { Increasing role of key account } \\
\text { managers as "primary marketing" } \\
\text { coordinators at the expense of } \\
\text { Product managers }\end{array}$ \\
\hline & & Gupta (2003) & Case study P\&G & USA & USA & FMCG & $\begin{array}{l}\text { Emergence of a cohort } \\
\text { management strategy targeting }\end{array}$ \\
\hline
\end{tabular}




\begin{tabular}{|c|c|c|c|c|c|c|c|}
\hline & & & & & & & consumers with similar needs \\
\hline & & Shapiro (2002) & $\begin{array}{c}\text { Case study on P\&G, } \\
\text { Campbell, Hewlett } \\
\text { Packard }\end{array}$ & USA & USA & $\begin{array}{c}\text { FMCG } \\
\text { \&High tech }\end{array}$ & $\begin{array}{l}\text { Creation of a consumer centric } \\
\text { team }\end{array}$ \\
\hline & & Lau et al. (2015) & $\begin{array}{l}\text { Experts report } \\
\text { (McKinsey) }\end{array}$ & Worldwide & Worldwide & $\begin{array}{c}150 \\
\text { companies }\end{array}$ & $\begin{array}{c}\text { Relevant digital capabilities as a key } \\
\text { asset }\end{array}$ \\
\hline & $\begin{array}{l}\text { Brand } \\
\text { managers as }\end{array}$ & $\begin{array}{l}\text { De Swaan Arons et al. } \\
\text { (2014) }\end{array}$ & Experts report (HBR) & Germany & Worldwide & $\begin{array}{l}\text { Industry } \\
+ \text { FMCG }\end{array}$ & $\begin{array}{l}\text { The brand manager should be an } \\
\text { orchestrator }\end{array}$ \\
\hline & facilitators & $\begin{array}{l}\text { Joshi and Gimenez } \\
\text { (2014) }\end{array}$ & $\begin{array}{c}\text { Experts report and case } \\
\text { study Nordstrom and } \\
\text { Target }\end{array}$ & $\begin{array}{c}\text { USA/ } \\
\text { EUROPE }\end{array}$ & USA & $\begin{array}{l}\text { Industry+ } \\
\text { FMCG }\end{array}$ & $\begin{array}{l}\text { Brand managers should work in } \\
\text { collaboration and cross functional } \\
\text { boundaries. }\end{array}$ \\
\hline & $\begin{array}{l}\text { Loss of control } \\
\text { overbrand } \\
\text { management }\end{array}$ & Quinton (2013) & Theoretical paper & UK & - & - & $\begin{array}{l}\text { Development of Brand } \\
\text { management in co-creation with } \\
\text { communities }\end{array}$ \\
\hline & & $\begin{array}{l}\text { Iglesias \& Bonet } \\
\text { (2012) }\end{array}$ & Theoretical paper & Spain & - & - & $\begin{array}{l}\text { Control over the process of brand } \\
\text { meaning is only partial. Brand } \\
\text { managers are only co-producers. }\end{array}$ \\
\hline & $\begin{array}{l}\text { New skills and } \\
\text { new positions }\end{array}$ & $\begin{array}{l}\text { Brinker \& McLellan } \\
\text { (2014) }\end{array}$ & Experts report (HBR) & USA & Worldwide & $\begin{array}{l}\text { Industry } \\
\text { +FMCG }\end{array}$ & $\begin{array}{l}\text { New specialist positions as Digital } \\
\text { privacy analyst or native content } \\
\text { editor emerge. }\end{array}$ \\
\hline & & $\begin{array}{l}\text { Brexendorf \&Daecke } \\
\text { (2012) }\end{array}$ & Case study Henkel & Germany & Germany & FMCG & $\begin{array}{l}\text { The brand managers should } \\
\text { combine analytic skills and creative } \\
\text { thinking }\end{array}$ \\
\hline & & Townsend et al. (2010) & $\begin{array}{c}\text { Case study General } \\
\text { Motors }\end{array}$ & USA & USA & Industry & $\begin{array}{l}\text { Building a brand requires unique } \\
\text { knowledge assets and the ability to } \\
\text { understand both divergence and } \\
\text { commonalities between markets } \\
\text { (global orientation) }\end{array}$ \\
\hline 岁 & $\begin{array}{l}\text { Rise of marketing } \\
\text { analytics }\end{array}$ & $\begin{array}{l}\text { Wedel \& Kannan } \\
\text { (2016) }\end{array}$ & $\begin{array}{l}\text { Research paper using a } \\
\text { historical approach }\end{array}$ & USA & $\begin{array}{l}\text { USA and } \\
\text { Europe }\end{array}$ & $\begin{array}{l}\text { Companies } \\
\text { and } \\
\text { agencies }\end{array}$ & Unprecedented volume of data \\
\hline
\end{tabular}


Impact of information technology leading to "service revolution" 